\title{
POTRET KONDISI PERAIRAN DI PULAU KARANG CONGKAK KEPULAUAN SERIBU, DKI JAKARTA
}

Oleh :

\author{
Agung Riyadi
}

Peneliti di Pusat Teknologi Lingkungan, Badan Pengkajian dan Penerapan Teknologi (BPPT)

\begin{abstract}
Pulau Panggang in Kepulauan Seribu district have many small corall island sand, many reef flat the island. Approximately have four island reefs and there are relatively wide, that are a P. Karang Semak Daun, P. Karang Beras, P. Karang Congkak and P. Karang Bongkok. Karang Congkak Island has reef flat and its area is more than 169,36 Ha, while land area is just only 0,6 $\mathrm{Ha}$ and 0,5-2 meter depth. Water quality include temperature distribution about $29,8-30,4{ }^{\circ} \mathrm{C}$, dissolved oxygen $6,001-7,110 \mathrm{mg} / \mathrm{L}$, salinity 32,891 33,214 PSU, turbidity 0,518 - 1,944 FTU,chlorophyll 0,204-0,563 ug/L and $\mathrm{pH}$ about $8,505-8,592$ and its quality relative normal. Current velocity about $0,102-0,407 \mathrm{~m} / \mathrm{s}$ at the reef flat, this conditions is relative height all along monsoon until corall reff many a massive type, at the some location have good corall conditon. Karang Congkak Island has potency for tourism maritime. Determining of sea protection at Karang Congkak island is very useful to preserve remainder corall reef existence.
\end{abstract}

Keywords : reef flat, waters quality, preserve area

\section{PENDAHULUAN}

\section{$1.1 \quad$ Latar Belakang}

Sebagai negara kepulauan yang terdiri atas 17.508 pulau, Indonesia memiliki garis pantai yang mencapai $80.791 \mathrm{~km}$. Sekitar dua per tiga dari pantai tersebut dilindungi oleh ekosistem terumbu karang. Ekosistem terumbu karang yang tersebar hampir di seluruh kawasan pesisir Indonesia, memberi manfaat ekonomi yang besar bagi Negara Indonesia, terutama bagi masyarakat yang hidup dalam sekitar 7.000 perkampungan di sepanjang kawasan pesisir ${ }^{(2)}$. Hampir sepertiga dari penduduk Indonesia yang tinggal di kawasan pesisir menggantungkan hidupnya pada perairan laut dangkal dimana terumbu karang banyak berasosiasi ${ }^{(5)}$.

Wilayah Kepulauan Seribu terdiri dari 110 pulau dan memiliki perairan laut seluas 699.750 $\mathrm{Ha}$, dari seratus lebih pulau tersebut hanya sekitar sepuluh pulau yang berpenghuni dengan sebagian besar masyarakatnya berprofesi sebagai nelayan. Secara administratif Kabupaten Kepulauan Seribu terbagi dalam 2 wilayah kecamatan dan 6 wilayah kelurahan. Kedua wilayah kecamatan tersebut adalah Kecamatan Kepulauan Seribu Utara dan Kecamatan Kepulauan Seribu Selatan.

Apabila diperhatikan, beberapa pulau di wilayah ini mempunyai hamparan karang mati (gosong) yang dangkal dan ada juga hamparan karang gosong yang terpisah dengan satu pulau yang berpenghuni maupun dengan pulau yang tidak ada penghuninya. Perairan laut ini relatif terlindung oleh karang penghalang (barrier reef) di sekitar pulau. Karang penghalang ini terlihat atau muncul ke permukaan ketika air laut mengalami surut dan masyarakat menyebutnya sebagai gudus.

Keadaan fisik, kimia dan biologi di beberapa pulau gosong tersebut sangat spesifik, baik dilihat dari biodiversity maupun dari flora dan fauna yang ada. Saat ini tekanan terhadap ekosistem terumbu karang terus meningkat, bahkan dalam 10 tahun terakhir kerusakan terumbu karang telah berlangsung hampir di seluruh perairan Indonesia. Hal itu berkaitan dengan pola pemanfaatan sumberdaya terumbu karang dengan segala kekayaan di dalamnya, yang dilakukan dengan cara-cara yang destruktif seperti penambangan karang untuk bahan bangunan, serta penangkapan ikan yang menggunakan bahan peledak dan racun sianida. Rusaknya ekosistem terumbu karang di perairan Kepulauan Seribu akhir-akhir ini sangat dirasakan oleh nelayan, yaitu menurunnya hasil tangkapan ikan.

Hasil penelitian $^{(1)}$, mengungkapkan bahwa dalam jangka waktu 10 tahun (1985-1995) secara umum tutupan karang di Kepulauan Seribu mengalami penurunan dari 23 persen pada 1985 menjadi 17 persen pada 1995. Kerusakan terumbu karang tersebut, diduga berkaitan dengan masih adanya penangkapan ikan dengan menggunakan racun sianida dan 
bahan peledak. Nelayan cenderung mengutamakan nilai ekonomi ikan hasil tangkapan dan tidak peduli dengan nilai terumbu karang sebagai sarana wisata bahari yang juga bisa memberi manfaat ekonomi yang besar, atau fungsi terumbu karang yang memberi perlindungan bagi kehidupan masyarakat pesisir.

Bertitik tolak dari uraian di atas, maka untuk mendorong pemanfaatan sumberdaya alam secara berkelanjutan, perlu diketahui potensi dan kondisi perairan P. Karang Congkak yang terletak di Kelurahan P. Panggang Kep. Seribu.

\section{PERALATAN DAN METODOLOGI}

\subsection{Lokasi Penelitian}

Lokasi penelitian berupa karang gosong yang relatif besar, yaitu Karang Congkak yang berada di dalam kawasan Taman Nasional Kepulauan Seribu. Secara administrasi Karang Congkak berada dalam wilayah Kelurahan Pulau Panggang. Lokasi pulau karang tersebut dapat dilihat pada Gambar 1 di bawah ini.



Gambar 1:Lokasi Penelitian di P. Karang Bongkok.

\subsection{Bahan dan Peralatan}

Untuk pelaksanaan survai identifikasi terumbu karang di beberapa Pulau Gosong tersebut dibutuhkan beberapa peralatan antara lain:
- Chlorotec Probe (type AAQ 1183, Alec Electronic)

- Global Position System (GPS)

- Varn Dorn

- Secchi Disk

- Echo Sounder

- Snookeling unit

- Current meter (Valeport)

\subsection{Metodologi}

Beberapa metodologi yang dipakai dalam penelitian ini adalah:

Survai fisik-kimia air (Chlorotech Probe,dll)

Survai kedalaman (Echo Sounder)

Survai terestrial (GPS, dII)

Survai terumbu karang (Manta Tow)

Survai kecepatan arus

\section{IDENTIFIKASI LOKASI}

Dari 13 pulau di Kelurahan Pulau Panggang, diperkirakan hanya 6 pulau yang memiliki potensi untuk pengembangan budidaya laut dan pelestarian terumbu karang, yaitu: Pulau Karang Bongkok, Pulau Kotok Kecil, Pulau Karang Congkak, Pulau Semak Daun, Pulau Panggang dan Pulau Air. Di antara 3 pulau dengan kawasan perairan laut dangkal yang relatif luas, yaitu: Pulau Karang Congkak, Pulau Karang Bongkok dan Pulau Semak Daun. Tabel 1 di bawah ini memperlihatkan jumlah pulau di Kecamatan Kepulauan Seribu Utara dan Kec. Kepulauan Seribu Selatan.

Tabel 1 : Jumlah Pulau Menurut Wilayah Kelurahan dan Kecamatan di Kabupaten Kepulauan Seribu

\begin{tabular}{|c|l|l|c|}
\hline No. & Kecamatan & \multicolumn{1}{|c|}{ Kelurahan } & $\begin{array}{c}\text { Jumlah } \\
\text { Pulau }\end{array}$ \\
\hline 1. & $\begin{array}{l}\text { Kepulauan } \\
\text { Seribu Utara }\end{array}$ & P. Panggang & 13 \\
\hline \multirow{2}{*}{2.} & $\begin{array}{l}\text { Kepulauan } \\
\text { Seribu } \\
\text { Selatan }\end{array}$ & P. Harapan & 30 \\
\cline { 3 - 4 } & & P. Kelapa & 36 \\
\hline \multirow{2}{*}{} & $\begin{array}{l}\text { P. Tidung } \\
\text { Jawa Untung }\end{array}$ & 6 \\
\cline { 3 - 4 } & P. Pari & 15 \\
\hline \multicolumn{2}{|r|}{ Jumlah } & $\mathbf{1 1 0}$ \\
\hline
\end{tabular}

Sumber : Laporan Penyelenggaraan Pemerintah Wilayah Kecamatan Kepulauan Seribu 2002.

Pada umumnya pulau-pulau di dalam wilayah Kelurahan Pulau Panggang dan Tidung, banyak dikelilingi oleh adanya karang penghalang (barrier reef) sehingga terbentuk perairan dangkal yang terlindung (karang gosong). 
Karang penghalang ini sebagian besar terlihat atau muncul ke permukaan air laut ketika terjadi air laut surut, akan tetapi sebagian kecil tetap di bawah permukaan air laut saat surut sekalipun. Bagian ini merupakan jalan keluar masuk air laut ke kawasan perairan laut dangkal dan berfungsi pula sebagai pintu keluar masuknya perahu nelayan.

Pada kawasan Karang Beras terdapat 2 (dua) laguna, diperkirakan memiliki luas total : 11,90 hektar, di Karang Congkak terdapat 1 (satu) laguna dengan luas 19,86 hektar, sedang di Karang Bongkok 1 (satu) laguna dengan luas : 23,58 hektar. Perairan ini memiliki kedalaman lebih dari 3 meter hingga 12 meter pada saat pasang. Data mengenai kondisi perairan karang dalam dari ketiga pulau karang tersebut dapat dilihat pada Tabel 2.

Tabel 2 :Luas Reef Flat dan Laguna di Perairan Dangkal Terlindung P. Karang Congkak, Karang Bongkok dan Karang Beras

\begin{tabular}{|c|c|c|c|c|c|}
\hline \multirow[t]{2}{*}{ Pulau } & \multirow{2}{*}{$\begin{array}{c}\text { Darata } \\
\mathrm{n} \\
(\mathrm{Ha})\end{array}$} & \multicolumn{3}{|c|}{$\begin{array}{l}\text { Perairan Karang } \\
\text { Dalam }(\mathrm{Ha})\end{array}$} & \multirow[t]{2}{*}{$\begin{array}{l}\text { Total } \\
\text { (Ha) }\end{array}$} \\
\hline & & $\begin{array}{l}\text { Reef } \\
\text { flat }\end{array}$ & $\begin{array}{c}\text { Lagu } \\
\text { na }\end{array}$ & $\begin{array}{l}\text { Sub } \\
\text { total }\end{array}$ & \\
\hline $\begin{array}{l}\text { P. Karang } \\
\text { Bongkok }\end{array}$ & 0,5 & 80,6 & 23,5 & $\begin{array}{r}103, \\
7\end{array}$ & 104,2 \\
\hline $\begin{array}{l}\text { P. Karang } \\
\text { Congkak }\end{array}$ & 0,60 & $\begin{array}{r}169 \\
3\end{array}$ & $\begin{array}{r}19,8 \\
6\end{array}$ & $\begin{array}{r}189, \\
2\end{array}$ & 189,82 \\
\hline $\begin{array}{l}\text { P. Karang } \\
\text { Beras }\end{array}$ & 4,36 & $\begin{array}{r}167 \\
3\end{array}$ & $\begin{array}{r}10,8 \\
1\end{array}$ & $\begin{array}{r}178, \\
1\end{array}$ & 182,43 \\
\hline
\end{tabular}

Sumber: Pengukuran lapangan 2005

Bagian perairan karang dalam terdiri dari reef flat dan mud flat adalah bagian yang paling dominan, dan diperkirakan mencapai luas 417,2 ha (Tabel 2). Kedalaman kawasan ini berkisar antara $3-12 \mathrm{~m}$ pada saat pasang. Pada saat surut beberapa reef flat tidak berair. Substrat dasar reef flat umumnya berupa pasir berkarang, baik karang mati maupun karang hidup, bercampur dengan pecahan karang dan cangkang moluska yang kosong. Bagian reef flat yang tidak berarus (stagnan), pada bagian dasarnya biasanya bersubstrat pasir yang mengandung lumpur sehingga disebut mud flat ${ }^{(4)}$ Teknik pengambilan sampel dilakukan mengelilingi Pulau Karang Congkak dan beberapa titik di dalam lagunanya. Lokasi pengambilan sampel dapat dilihat pada Gambar 2 di bawah ini. Titik biru muda memperlihatkan sebaran pengambilan sampel kedalaman mengelilingi $\mathrm{P}$. Karang Congkak, sedangkan titik merah merupakan titik pengambilan chlorotech probe yang merupakan titik pengambilan kualitas air dan pengukuran kecepatan arus.

\subsection{Kondisi Fisik Oseanografi}

Kondisi Oseanografi di kawasan perairan laut dangkal (perairan karang dalam) di sekitar Pulau Karang Congkak berbeda dengan perairan laut di kawasan karang luar (sebelah luar dari barrier reef) yang pada umumnya dipengaruhi oleh iklim makro di Kepulauan Seribu.

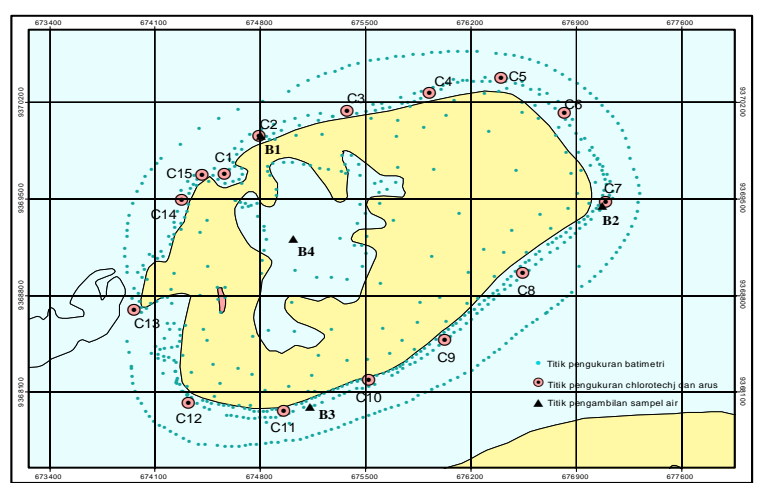

Gambar 2 : Lokasi Pengambilan Sampel di Pulau Karang Congkak.

Perairan laut dangkal di sekitar pulau tersebut umumnya dipengaruhi oleh kondisi geofisik kawasan yang berbeda antara satu pulau dengan yang lainnya.

Kondisi dan kecepatan arus di dalam kawasan perairan karang dalam sangat berbeda dengan di luar karang dalam (karang luar). Arus dan gelombang di luar kawasan karang dalam setelah melewati karang penghalang (barrier reef) akan berubah sama sekali. Arus dan gelombang turbulen dan cepat berubah menjadi arus dan gelombang laminar (tenang) dan lambat. Kecepatan arus berkisar antara 0,064 $\mathrm{m} / \mathrm{dtk}$ sampai $0,448 \mathrm{~m} /$ detik. Kecepatan arus di perairan reef flat umumnya lebih tinggi dibandingkan dengan di goba (laguna).

\section{- Batimetri}

Kedalaman perairan di Kepulauan Seribu sangat bervariasi, dimana beberapa lokasi mencatat kedalaman hingga lebih dari 50 meter, seperti lokasi antara Pulau Karang Congkak dan Pulau Karang Beras. Setiap pulau umumnya dikelilingi oleh paparan pulau yang cukup luas (island shelf) hingga 20 kali lebih luas dari pulau yang bersangkutan dengan kedalaman kurang dari 5 meter. Di setiap pulau karang memiliki daerah rataan karang (reef flat) dengan kedalaman rerata 0,5 meter hingga 2 meter. Setelah rataan terumbu diikuti tubir dengan kedalaman mencapai puluhan meter dengan kemiringan mencapai $70^{\circ}$. Dasar rataan karang merupakan variasi antara pasir, karang mati, sampai karang batu hidup. Gambar kontur batimetri di pulau Karang Beras disajikan di dalam Gambar 3 di bawah ini. Gambar kontur kedalaman ini merupakan hasil dari pengambilan data kedalaman di lapangan dan kemudian di 
plot ke dalam komputer dan disimulasikan dengan Arcview 3D.



Gambar 3 : Peta Kontur Batimetri Pulau Karang Congkak.

\section{- Pasang Surut}

Berdasarkan pengukuran di stasiun penelitian oleh ITB Bandung tahun 2001 yang berlokasi di Pulau Untung Jawa pada koordinat 0558'45,21" LS - 10642'11,07" BT, kondisi pasang surut di Kepulauan Seribu dapat dikategorikan sebagai harian tunggal. Kedudukan air tertinggi dan terendah adalah 0,6 dan 0,5 meter dibawah duduk tengah. Rata-rata tunggang air pada pasang perbani adalah 0,9 meter dan rata-rata tunggang air pada pasang mati adalah 0,2 meter. Tunggang air tahunan terbesar mencapai 1,10 meter ${ }^{(3)}$. Pengamatan pada tahun 1999 di P. Pramuka, P. Karya dan P. Panggang mencatat tinggi muka laut rata-rata sebesar $1,01 \mathrm{~m}$ pada skala palem dan tinggi referensi kedalaman peta (chart datum) sebesar $0,65 \mathrm{~m}$ di bawah muka laut rata-rata (Jurusan Teknik Geodesi-ITB).

\section{- Arus}

Kecepatan arus di Pulau Karang Congkak berkisar 0,102 - 0,407 m/det. Umumnya kecepatan arus di laguna (goba) relatif lebih kecil daripada di luar rataan terumbu karang, kecepatannya berkisar 0,077 - 0,107 m/det. Pengukuran kecepatan arus ini menggunakan current meter model Valeport ${ }^{(4)}$.

Proyek Seawatch - BPPT pernah melakukan mooring bouy di sekitar P. Kelapa bulan Nopember - Desember 1998 dan mendapatkan kecepatan arus pada kisaran 0,6 cm/dt hingga $77,3 \mathrm{~cm} / \mathrm{dt}$ dengan rata-rata kecepatan sebesar 23,6 cm/dt dengan dominasi arah arus ke arah Timur - Timur Laut.

\section{HASIL}

\subsection{Kualitas Perairan}

\section{- Suhu}

Kisaran suhu hasil pengamatan di Pulau Karang Congkak dan perairan disekitar pulau berkisar diantara $29,80-30,40^{\circ} \mathrm{C}$. Profil melintang suhu di perairan Pulau Karang Congkak ditampilkan dalam Gambar 4. Distribusi suhu pada perairan ini menggambarkan distribusi suhu normal suatu perairan pantai. Lapisan permukaan sepanjang keliling pulau Karang Congkak menunjukkan nilai suhu yang lebih tinggi dibanding perairan yang lebih dalam.

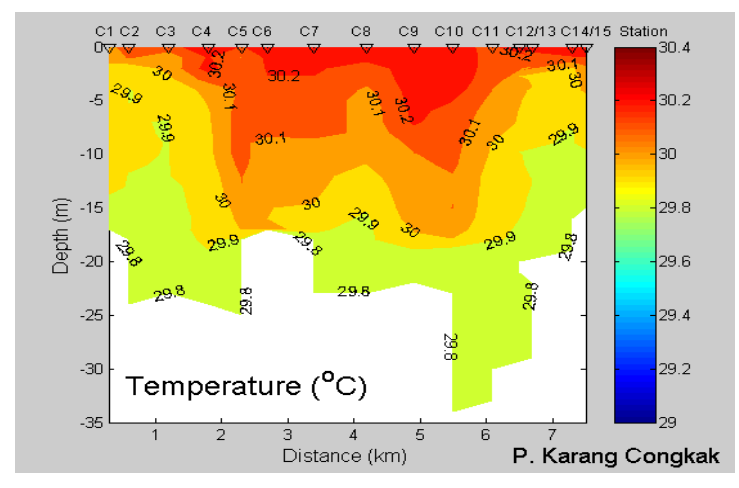

Gambar 4. Penampang Melintang Suhu di Perairan Pulau Karang Congkak

\section{- Salinitas}

Kisaran salinitas hasil pengamatan di Pulau Karang Congkak dan perairan disekitar pulau berkisar 32,891 - 33,214 PSU. Gambar sebaran vertikal salinitas di P. Karang Congkak dapat dilihat pada Gambar 5 di bawah ini.

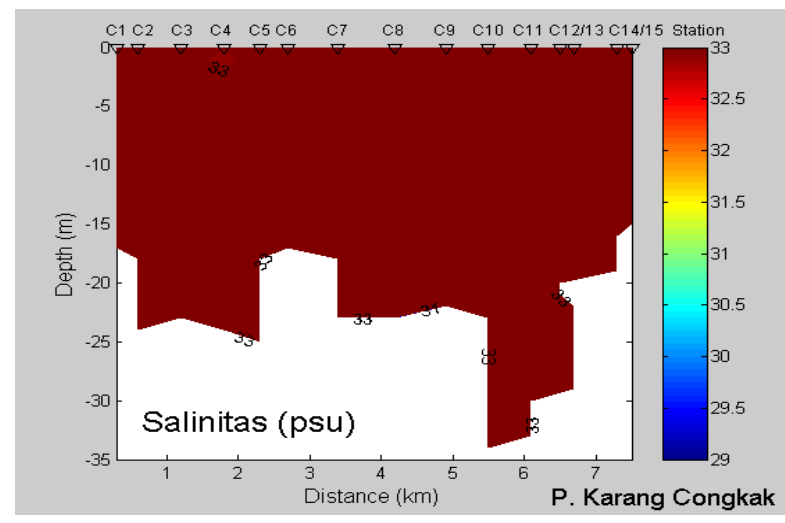

Gambar 5. Penampang Melintang Salinitas di Perairan Pulau Karang Congkak.

\section{- Turbiditas}

Turbiditas akan mengganggu proses fotosintesa karena menghalangi masuknya sinar matahari. Kisaran turbiditas hasil pengamatan di Pulau Karang Congkak dan perairan disekitar pulau berkisar 0,518 - 1,944 ftu. Dari hasil pengamatan turbiditas di perairan 
mengindikasikan bahwa kondisi turbiditas perairan di Pulau karang Congkak d masih relatif baik. gambar distribusi secara vertikal dapat dilihat pada Gambar 6 di bawah ini.

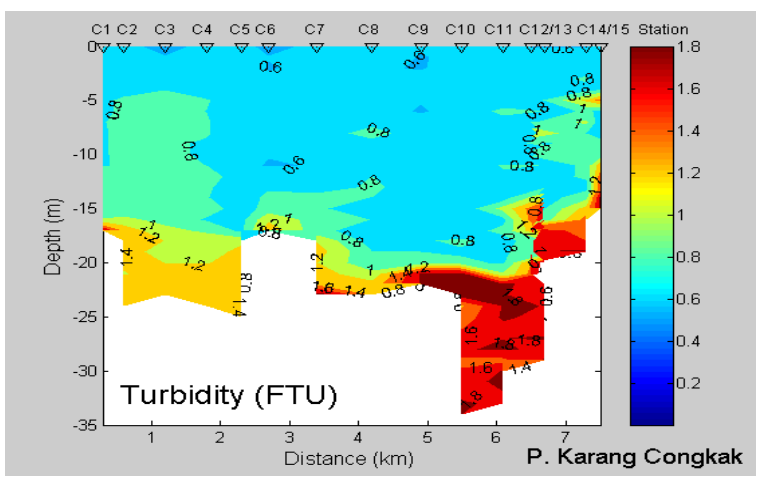

Gambar 6: Penampang Melintang Turbiditas di Perairan Pulau Karang Congkak.

\section{- $\quad$ Oksigen Terlarut (DO)}

Kisaran oksigen terlarut hasil pengamatan di perairan Pulau Karang Congkak dan perairan disekitar pulau berkisar antara 6,001 - 7,110 $\mathrm{mg} / \mathrm{L}$. Distribusi oksigen terlarut pada perairan umumnya mempunyai nilai tinggi di lapisan permukaan, kemudian konsentrasinya bertahap menurun dengan bertambahnya kedalaman. Tingginya konsentrasi oksigen terlarut di lapisan permukaan disebabkan karena optimalnya proses fotosintesa di lapisan ini yang ditunjang oleh intensitas cahaya matahari dan supplay nutrient yang cukup. Dengan bertambahnya kedalaman konsentrasi oksigen juga semakin menurun.

Pola distribusi oksigen terlarut di perairan Pulau Karang Congkak menunjukkan pola yang normal, sedangkan penampang melintang nilai oksigen terlarut dapat dilihat pada Gambar 7 di bawah ini.

\section{- $\mathrm{pH}$}

Air laut mempunyai kemampuan menyangga yang sangat besar untuk mencegah perubahan $\mathrm{pH}$. Perubahan $\mathrm{pH}$ sedikit saja dari $\mathrm{pH}$ alami akan memberikan petunjuk terganggunya sistem penyangga. Hal ini dapat menimbulkan perubahan dan ketidak seimbangan kadar $\mathrm{CO}_{2}$ yang dapat membahayakan kehidupan biota laut. $\mathrm{pH}$ air laut permukaan di Indonesia umumnya bervariasi di setiap lokasi yaitu antara 6,0 - 8,5. Perubahan $\mathrm{pH}$ dapat mempunyai akibat buruk terhadap kehidupan biota laut, baik secara langsung maupun tidak langsung. Akibat langsung adalah kematian ikan, telur, dan lain-lainnya, serta mengurangi produktivitas primer.

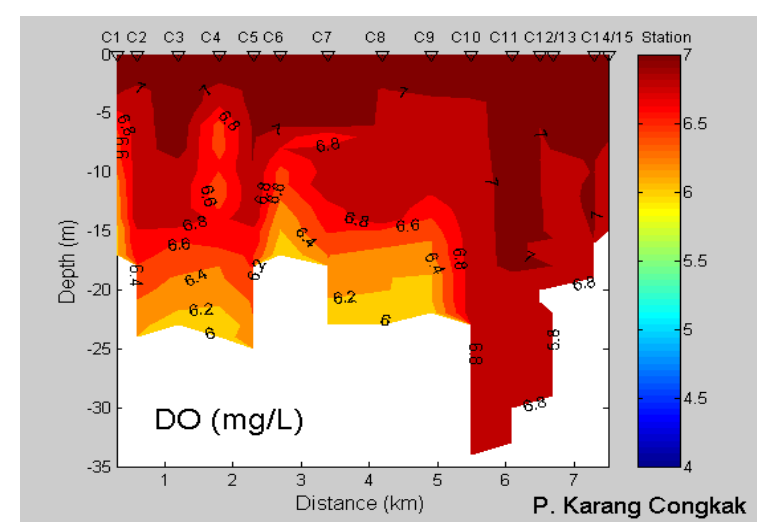

Gambar 7 : Penampang Melintang DO di Perairan Pulau Karang Congkak.

Kisaran $\mathrm{pH}$ hasil pengamatan di perairan Pulau Karang Congkak dan perairan disekitar pulau tersebut berkisar 8,503 - 8,592. Gambar melintang sebaran pH di Pulau Karang Congkak dapat dilihat pada Gambar 8 di bawah ini.

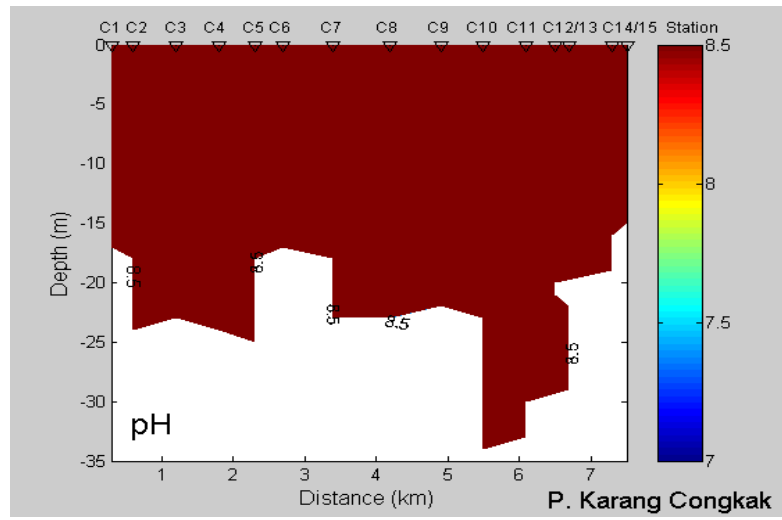

Gambar 8: Penampang Melintang pH di Perairan Pulau Karang Congkak.

\section{- Klorofil}

Kisaran klorofil a hasil pengamatan di perairan Pulau Karang Congkak dan perairan disekitarnya berkisar 0,204 - 0,563 ug/L. Gambar penampang melintang disajikan dalam Gambar 9 di bawah ini ${ }^{(5)}$.

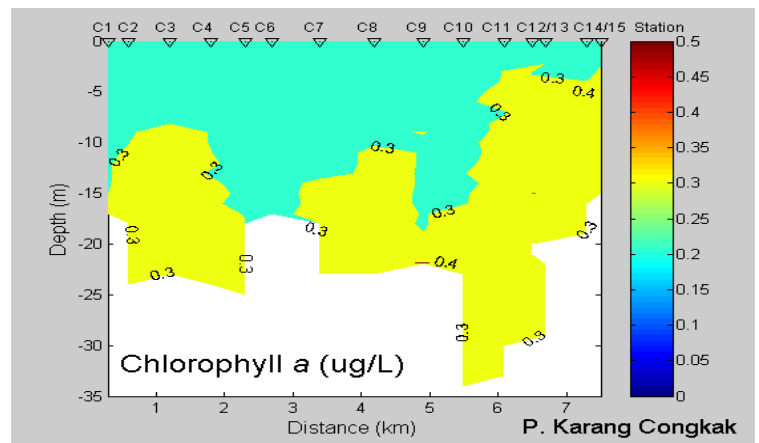

Gambar 9 : Penampang Melintang Klorofil a di Perairan P. Karang Congkak 


\subsection{Terumbu Karang}

Terdapat 2 kelompok besar di sekeliling Pulau Karang Congkak. Pengelompokan ini didasarkan pada intensitas areal perairan pulau tersebut menerima hempasan angin barat maupun angin timur (Gambar 10). Kelompok pertama adalah areal karang yang secara rutin terkena hempasan angin barat atau angin timur yakni di bagian timur dan bagian barat.

Pada areal pertama, terumbu karang di areal ini didominasi oleh jenis karang coral massive. Jenis karang ini mendominasi karena karang ini paling tahan terhadap hempasan ombak dibanding jenis karang lain. Jenis lain yang ditemui dalam kelompok ini adalah jenis Coral massive, Coral mushroom, Coral branching, Acropora tabulate, Acropora submassive, Acropora bleanching dan beberapa jenis soft coral yang tumbuh di atas coral massive yang mati.

Pada areal kedua, jenis terumbu karang lebih bervariasi dengan didominasi oleh jenis Acropora, baik jenis Acropora tabulate, Acropora Encrusting maupun Acropora brancing ${ }^{(4)}$.

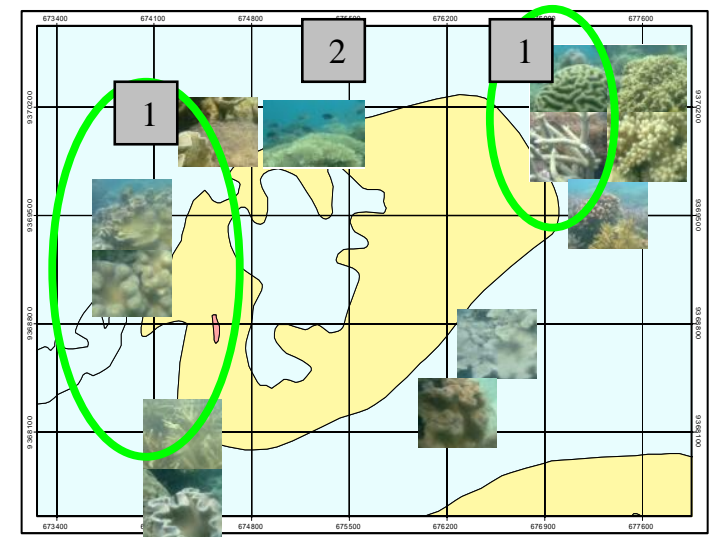

Gambar 10 : Sebaran Terumbu Karang di Pulau Karang Congkak.

\section{KESIMPULAN DAN SARAN}

Kondisi suhu di perairan Pulau Karang Congkak menggambarkan bahwa kondisi suhu perairan seperti halnya pada perairan umum lainnya. Suhu perairan meningkat pada daerah pantai dan daerah lapisan perrmukaan, kemudian suhu turun berdasarkan peningkatan kedalaman. Kisaran suhu di perairan Pulau Karang Congkak berkisar antara 29,80 - 30,40 ${ }^{\circ} \mathrm{C}$. Salinitas di perairan Pulau Karang Congkak cenderung homogen dengan kisaran nilai antara : 32,89-33,21 PSU. Nilai Turbiditas (kekeruhan) mengindikasikan bahwa kondisi turbiditas perairan relatif baik.
Pola distribusi oksigen terlarut di perairan Pulau Karang Congkak menunjukkan pola yang normal. Kisaran oksigen terlarut di Pulau Karang Congkak adalah 6,01-7,11 mg/l. Kisaran umum konsentrasi $\mathrm{pH}$ homogen dengan kisaran 8,38,5 .

Kecepatan arus di Pulau Karang Congkak berkisar 0,102 - 0,407 m/det. Umumnya kecepatan arus di laguna (goba) relatif lebih kecil daripada di luar rataan terumbu karang, kecepatannya berkisar $0,077-0,107 \mathrm{~m} /$ det.

Kondisi terumbu karang di Pulau Karang Congkak didominasi dengan coral yang massive dan banyak dijumpai jenis Coral massive, Coral mushroom, Coral branching, Acropora tabulate, Acropora submassive, Acropora bleanching dengan persentase penutup karangnya kurang dari 15 persen. Arus lautnya relatif kuat sepanjang musim sehingga sebagian besar (coral massive) yang bisa bertahan. Beberapa (soft coral) juga dijumpai di beberapa tempat dengan hidup menempel di atasnya.

Di Pulau Karang Congkak dikelilingi oleh rataan terumbu karang hingga 120 kali lebih luas dari daratan pulau tersebut. Kedalaman rataan terumbu karang berkisar antara 0,5 - 3 meter. Sedangkan di laguna (goba) kedalaman berkisar $4-10 \mathrm{~m}$. Melihat dari luasnya rataan terumbu, sebaiknya di buat Daerah Perlindungan Laut (DPL) di daerah tersebut untuk melindungi keberadaan terumbu karang yang masih tersisa

Perairan laut di sekitar karang gosong Karang Congkak mempunyai potensi untuk dikembangkan sebagai salah satu obyek wisata bahari bagi resor-resor yang sudah ada dan wisatawan lokal yang mampir di Pulau Pramuka. Adapun kegiatan wisata bahari yang dapat di kembangkan seperti : melihat kekayaan alam di bawah laut melalui penyelaman (scuba diving), snorkeling, melihat keanekaragaman biodiversity laut, berenang dan memancing.

\section{DAFTAR PUSTAKA}

1. DeVantieJ, L., Suharsono, Agus Budiyanto, Yosephine Tuti, Philip Imanto and Rene Ledesma. 1998. Status of Coral Communities of Pulau Seribu, 1985-1995. In; Proceedings: Coral Reef Evaluation Workshop Pulau Seribu, Jakarta Indonesia. Study No. 10. UNESCO Jakarta Office. pp. 1-24

2. Djohani, R. H. 1994. Pattern of spatial distribution, diversity and cover of corals in Pulau Seribu National Park: Implication for the design of core coral sanctuaries, $3^{\text {rd }} I O C$ WESTP AC Conferenqe on the Sustainability of the Marine Environment", an integrated 
approach to coastal area management, Bali, Indonesia.

3. Fakultas Perikanan IPB, 1998. Laporan Studi Penetapan Lokasi Pengembangan Budidaya Laut di Kepulauan Seribu 1997/1998, Kerjasama Dinas Perikanan DKI Jakarta dengan Fakultas Perikanan IPB

4. Laporan Final Pemanfaatan Pulau Gosong Di Kepulauan Seribu yang meliputi Pulau Karang Beras, Karang Congkak dan Karang Bongkok, Dinas Perikanan Suku Dinas Perikanan dan Kelautan Kabupaten
Administrasi Kepulauan Seribu dan PT. Parikesit Indotama

5. Suharsono, 1998. Distribusi, Metodologi dan Status Terumbu Karang di Indonesia. Konperensi Nasional I Pengelolaan Sumberdaya Pesisir dan Lautan Indonesia. PKSPL. IPB. 